\title{
Effect of electrical discharge on the properties of natural esters insulating fluids
}

\author{
Imran Sutan Chairul ${ }^{1}$, Sharin Ab Ghani², Nur Hakimah Ab Aziz ${ }^{3}$, Mohd Shahril Ahmad Khiar ${ }^{4}$, \\ Muhammad Syahrani Johal ${ }^{5}$, Mohd Aizzat Azmi ${ }^{6}$ \\ ${ }^{1-4}$ High Voltage Engineering Research Laboratory, Fakulti Kejuruteraan Elektrik, \\ Universiti Teknikal Malaysia Melaka, Malaysia \\ ${ }^{5}$ Fakulti Teknologi Kejuruteraan Elektrik dan Elektronik, Universiti Teknikal Malaysia Melaka, Malaysia \\ ${ }^{6}$ EIC Advance Sdn. Bhd., Putrajaya, Malaysia
}

\begin{tabular}{|c|c|}
\hline Article Info & ABSTRACT \\
\hline Article history: & Vegetable oils have been an alternative to mineral oil for oil-immersed \\
\hline Received May 9, 2021 & $\begin{array}{l}\text { transformers due to concern on less flammable, environmental-friendly, } \\
\text { biodegradable, and sustainable resources of petroleum-based insulating oil. }\end{array}$ \\
\hline Revised Jul 16, 2021 & This paper presents the effect of electrical discharges (200 up to 1000 \\
\hline Accepted Jul 29, 2021 & $\begin{array}{l}\text { discharges) under } 50 \mathrm{~Hz} \text { inhomogeneous electric field on the properties } \\
\text { (acidity, water content, and breakdown voltage) of two varieties of vegetable- }\end{array}$ \\
\hline Keywords: & $\begin{array}{l}\text { based insulating oils; i) natural ester }(\mathrm{NE}) \text { and ii) low viscosity insulating fluids } \\
\text { derived from a natural ester }\left(\mathrm{NE}_{\mathrm{LV}}\right) \text {. Results show the water content, acidity }\end{array}$ \\
\hline $\begin{array}{l}\text { Breakdown voltage } \\
\text { Electrical discharges } \\
\text { Natural ester } \\
\text { PDIV }\end{array}$ & $\begin{array}{l}\text { and breakdown voltage of } \mathrm{NE} \text { fluctuate due to applied discharges, while } \mathrm{NE}_{\mathrm{LV}} \\
\text { display insignificant changes. Hence, results indicate that the low viscosity } \\
\text { insulating fluids derived from natural ester tend to maintain their properties } \\
\text { compared to natural ester. }\end{array}$ \\
\hline
\end{tabular}

Viscosity

This is an open access article under the $\underline{C C B Y-S A}$ license.

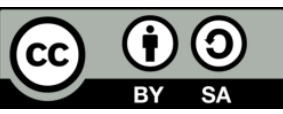

\section{Corresponding Author:}

Sharin Ab Ghani

Fakulti Kejuruteraan Elektrik

Universiti Teknikal Malaysia Melaka

Hang Tuah Jaya, 76100 Durian Tunggal, Melaka, Malaysia

Email: sharinag@utem.edu.my

\section{INTRODUCTION}

Mineral insulating oil (MO) is extensively used worldwide for over a century due to its adequate ageing behaviour, good dielectric strength, low viscosity, less susceptible to oxidation, effectively good operation in low temperature, widely available petroleum resources, compatible and reliable used in transformer as well as cost benefit [1]. Yet, disadvantages of MO such as non-biodegradable properties, enforcement of environmental laws, and limited reserves of naphthenic crude oil in future have directed to the quest for alternative fluids [2], [3].

Exploration on alternative insulating oil to replace existing MO have started nearly four decades back [4], where researches on vegetable-based insulating oil as an alternatives to MO are gaining much attention [5]-[8]. To date, vegetable-based insulating oil is being developed from edible oil. For example coconut oil, sunflower oil, soybean oil, rapeseed oil, and palm oil [9]-[15]. Other researches carried out in the field of non-edible oil. For example Pongamia pinnata oil, Jatropha curcas oil, Terminalia catappa oil, karanji oil, sesbania seeds oil, and castor oil [16]-[22]. According to BS EN 62770 [23], there are two categories of vegetable-based insulating oil: i) mainly triglycerides natural esters (NE) and 2) low-viscosity insulating fluids derived from natural esters $\left(\mathrm{NE}_{\mathrm{LV}}\right)$. Contrast to mineral oils, $\mathrm{NE}$ are usually characterized by its high flash 
point (less flammable), yet have higher viscosity and a higher pour point. On the other hand, properties of the $\mathrm{NE}_{\mathrm{LV}}$ are close to those of mineral oils (i.e., low flash point, low pour point and low viscosity). Most of the studies regarding electrical discharges in dielectric liquid are focused on mineral oil, while only few were regards to natural esters and synthetic esters [24]-[27]. Electrical discharges could be divided into; i) low; ii) medium; and iii) high energy discharges [26]. The discharge magnitude for low (e.g., corona) and medium (e.g., partial discharge) energy discharge was around $2.5 \mathrm{nC}$ and $20 \mathrm{nC}$, respectively. While arcing is a high energy discharges type. This paper presents the effect of 200 and up to 1000 electrical discharges (i.e., under $50 \mathrm{~Hz}$ inhomogeneous electric field) on the properties (acidity, water content and breakdown voltage) of two types of vegetable-based insulating oils i) $\mathrm{NE}$ and ii) $\mathrm{NE}_{\mathrm{LV}}$.

\section{RESEARCH METHOD}

Methodology adapted in this study is summarized in a flow chart, as shown in Figure 1.

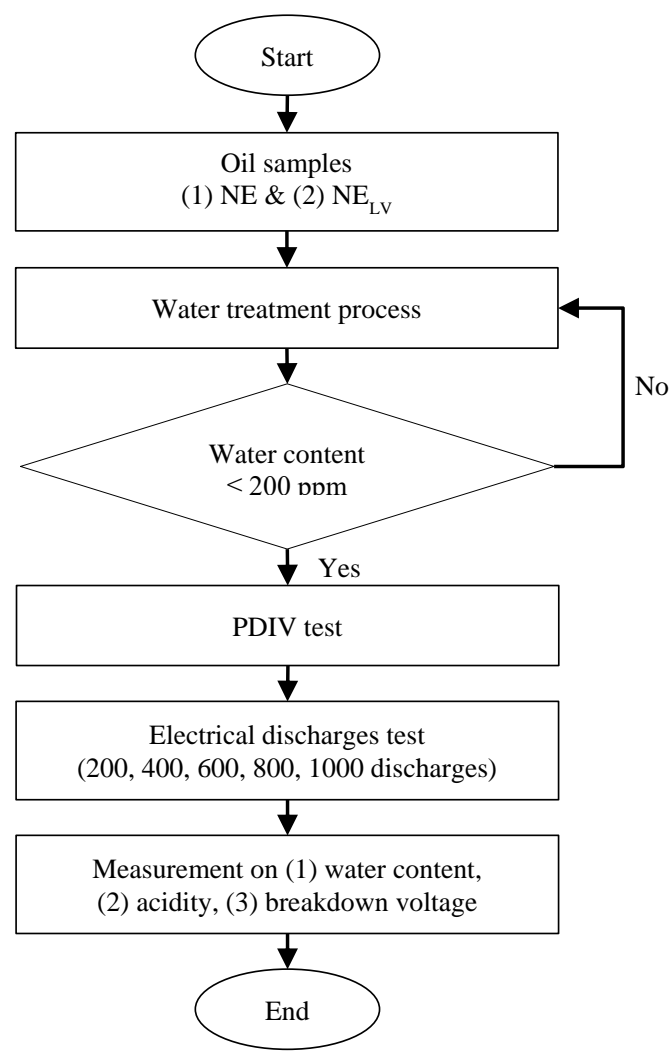

Figure 1. Flow chart of methodology adapted in this study

\subsection{Sample preparation}

In order to standardize the water content of oil samples to be less than or equal to $200 \mathrm{ppm}$ (i.e., the stipulated limits for water content of "new natural ester fluids"), both oil samples; i) NE and ii) NE treated via water treatment process. The process was done by bubbling nitrogen gas into oil samples [28] for 30 minutes or until the water content limits are fulfilled.

\subsection{Partial discharge inception voltage (PDIV) test}

The block diagram for partial discharge inception voltage (PDIV) measurement is as shown in Figure 2. The PDIV is defined as the voltage at which partial discharge occurs with an apparent charge equal or greater than $100 \mathrm{pC}$. The PDIV of the oil samples were measured using Omicron MPD600 partial discharge measurement device. The PDIV test setup was calibrated according to the IEC 60270 standard. The experimental apparatus was placed within a Faraday cage to minimize unwanted noise during the PDIV measurements.

After the equipment setup for PDIV measurement was free from discharges, the pre-processing sample ( $400 \mathrm{ml})$ was filled in a test cell as shown in Figure 3. The test cell consisted of a glass vessel with a 
tungsten needle (tip radius: $3 \mu \mathrm{m}$, length: $50 \mathrm{~mm}$, diameter: $1 \mathrm{~mm}$ ) and a brass plane electrode (diameter: 40 $\mathrm{mm}$, thickness: $10 \mathrm{~mm}$ ) separated by a vertical gap $(50 \mathrm{~mm})$. The needle electrode acts as the high voltage electrode whereas the plane electrode acts as the grounding electrode. The sample was allowed to rest for 15 minutes before the first voltage was applied. The voltage was increased from 0 at $1 \mathrm{kV} / \mathrm{s}$ until partial discharge was occurring above the threshold of $100 \mathrm{pC}$. The voltage applied was then decreased to 0 . The voltage level during partial discharge initiations was recorded. Measurement on the sample was repeated 10 times. After the measurement were completed, the oil was drained from the test cell. Following this, the test cell was cleaned, and a new needle electerode was inserted. With that, measurement of PDIV on new oil sample was take place.

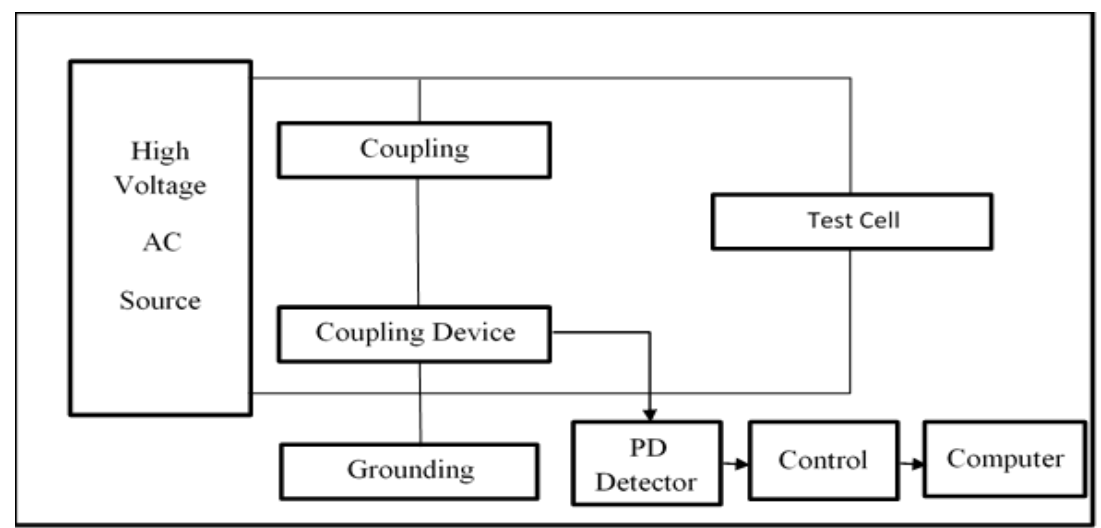

Figure 2. Block diagram for PDIV measurement [29]

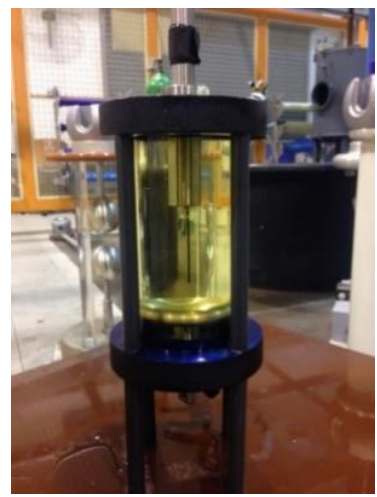

Figure 3. Test cell for PDIV and electrical discharges measurement

\subsection{Electrical discharge test}

Electrical discharges (i.e., the applied voltage at which partial discharge occurs with an apparent charge equal or greater than $100 \mathrm{pC}$ ) were applied and counted with a series of 200 successive discharges (i.e., 200, 400, 600, 800 and 1000 discharges) on the oil samples; i) NE and ii) $\mathrm{NE}_{\mathrm{LV}}$. After each series of discharges, water content, acidity and breakdown voltage of oil samples are measured.

\subsection{Water content}

Water content of oil sample was determined based on the oxidation of sulphur dioxide by iodine in methanolic hydroxide solution. Measurement of water content in oil was done based on ASTM D1533 standard [30] by using 899 Karl Fischer coulometer (Metrohm). Firstly, hydranal-coulomat (100 ml) was injected into an electrolysis cell. Next, a $5 \mathrm{ml}$ syringe filled with $1 \mathrm{ml}$ of oil sample was weighed using a precision balance. Then the oil sample was injected into the electrolysis cell. The wighted of oil sample were keyed into the coulometer, where titration process was initiated. The water content of the oil sample shown on the display monitor was recorded. The water content measurement was repeated three times for each oil sample in order to ensure consistency of the results. 


\subsection{Acidity}

Acidity or total acid number (TAN) test is a measurement of acidity that determines the sum of all acid compounds present in insulating oil samples. TAN was measured based on the amount of potassium hydroxide (in $\mathrm{mg}$ ) required to neutralize hydrogen ions $\left(\mathrm{H}^{+}\right)$in $1 \mathrm{~g}$ of oil sample. TAN is expressed in $\mathrm{mg} \mathrm{KOH/g}$. In this work, TAN was measured using a compact titrator (Model: 848 Titrino plus, Metrohm) according to the ASTM D974 standard [31]. Before any measurement wants to be conducted, the electrode was calibrated first with three buffer points, $\mathrm{pH} \mathrm{4,7}$ and 9 at room temperature. The calibration assessment was repeated twice by using new buffer solutions. Next, a standardization step was conducted to examine the actual concentration of potassium hydroxide in isopropanol (IPA) with a molarity of $0.1 \mathrm{~mol} / \mathrm{L}$ by weighing around $0.1 \mathrm{~g}$ of potassium hydrogen phthalate (KHP) and added approximately $80 \mathrm{~mL}$ of distilled water into a same beaker. This step was repeated twice with new KHP and distilled water in a new clean beaker. After that, $20 \mathrm{~mL}$ of solvent was inserted into another beaker and its acidity was measured as a blank solvent. This step was repeated two times with fresh $20 \mathrm{~mL}$ of solvent into another clean beaker. For acidity measurement on oil sample: Firstly $5 \mathrm{~g}$ of oil sample was weighted using a syringe. Then, the oil sample was poured into a beaker with $20 \mathrm{~mL}$ of solvent. After that, the solvent-oil sample mixture is titrated IPA to obtain the TAN. Each sample was tested for three times in order to ensure consistency of the results.

\subsection{Breakdown voltage}

Breakdown voltage of oil sample was measured according to ASTM D1816 standard [32] by using OTS60PB portable oil tester (megger). The equipment is capable to measure breakdown voltage up to $60 \mathrm{kV}$. The electrode configuration for the test setup were two semi-sphere electrodes of the Verband Deutscher Elektrotechniker (VDE) with the gap distance of $1 \mathrm{~mm}$. Firstly, a minimum volume of $350 \mathrm{ml}$ oil was slowly poured into a test cell, to ensure no bubble trap in the oil. Then, the temperature of the oil sample was measured prior to the test. The test was conducted within range temperature of $20^{\circ} \mathrm{C}$ to $30^{\circ} \mathrm{C}$. After the electrode immersed into sample oil and left to rest, voltage was increased gradually at a rate of $0.5 \mathrm{kV} / \mathrm{s} \pm 5 \%$ until breakdown occurs. The voltage at which breakdown occurs was recorded as the breakdown voltage. A settledown period of $1 \mathrm{~min}$ was set between repetition tests to assure the result obtained for the next test is not affected by the previous test. Based on ASTM D1816 standard, one breakdown cycle consists of five individual tests in sequence, where the mean values of the breakdown voltage for five individual tests were determined.

\section{RESULTS AND DISCUSSIONS}

The oil samples; i) $\mathrm{NE}$ and ii) $\mathrm{NE}_{\mathrm{LV}}$ were firstly treated via water treatment process. As the water content is satisfying the limit as stated in standard, the PDIV on both oil samples were then determined. The PDIV levels will be a reference for executing the electrical discharges tests. After electrical discharges experiment on oil samples were done, its properties (water content, acidity, and breakdown voltage) were measured, presented and discussed.

\subsection{Sample preparation}

Table 1 shows the properties (water content, acidity, viscosity, breakdown voltage) and PDIV of oil samples ( $\mathrm{NE}$ and $\mathrm{NE}_{\mathrm{LV}}$ ) used in this study after being treated through water treatment technique (i.e., nitrogen bubbling in the oil samples). It can be seen that the properties of both $\mathrm{NE}$ and $\mathrm{NE}_{\mathrm{LV}}$ satisfying the limit stipulated in ASTM D6871 standard [33], where; i) water content should be $\leq 200 \mathrm{ppm}$; ii) acidity should be $\leq$ $0.06 \mathrm{mg} \mathrm{KOH} / \mathrm{g}$; iii) viscosity should be $\leq 50 \mathrm{~mm}^{2} / \mathrm{s}$; and iv) breakdown voltage should be $\geq 20 \mathrm{kV}$. Noted that the viscosity of $\mathrm{NE}_{\mathrm{LV}}\left(8 \mathrm{~mm}^{2} / \mathrm{s}\right)$ is lower than viscosity of $\mathrm{NE}\left(35 \mathrm{~mm}^{2} / \mathrm{s}\right)$. At the same time, the viscosity of $\mathrm{NE}_{\mathrm{LV}}$ is also close to those of mineral oils, as according to ASTM D3487 standard [34], where viscosity should be $\leq 12 \mathrm{~mm}^{2} / \mathrm{s}$. As for PDIV, it shows that PDIV of $\mathrm{NE}_{\mathrm{LV}}$ is higher than PDIV of NE. Similarly, breakdown voltage of $\mathrm{NE}_{\mathrm{LV}}$ is higher than PDIV of NE. One reason of $\mathrm{NE}_{\mathrm{LV}}$ having higher PDIV and higher breakdown voltage compared to $\mathrm{NE}$ is might be due to its low viscosity.

Table 1. The properties of oil samples after water treatment

\begin{tabular}{lccc}
\hline \multicolumn{1}{c}{ Properties } & Unit & \multicolumn{2}{c}{ Natural ester oil samples } \\
& & $\mathrm{NE}$ & $\mathrm{NE}_{\mathrm{LV}}$ \\
\hline Water content & $\mathrm{mg} / \mathrm{kg}$ & 150.20 & 141.60 \\
Acidity & $\mathrm{mg} \mathrm{KOH} / \mathrm{g}$ & 0.0056 & 0.0304 \\
Viscosity & $\mathrm{mm} / \mathrm{s}$ & 35 & 8 \\
Breakdown voltage & $\mathrm{kV}$ & 24.92 & 26.66 \\
PDIV & $\mathrm{kV}$ & 15.42 & 17.87 \\
\hline
\end{tabular}

Indonesian J Elec Eng \& Comp Sci, Vol. 23, No. 3, September 2021: 1281 - 1288 


\subsection{Water content}

Figure 4 shows the water content of $\mathrm{NE}$ and $\mathrm{NE}_{\mathrm{LV}}$ samples after subjected to electrical discharges. It can be said that the water content of both $\mathrm{NE}$ and $\mathrm{NE}_{\mathrm{LV}}$ oil samples were unchanged up to 400 discharges. However, water content of NE started to fluctuate (decreased, and increased) for the remaining discharges. Initial water content of NE is $150.20 \mathrm{ppm}$ but decrease to $73.74 \mathrm{ppm}$ after 1000 electrical discharges. The reduction in water content with the application of discharges on NE might be due to evaporation of water traces that are present in the zone of discharges occurrence. Moreover, NE contain unsaturated fatty acid, where easily influence by stresses. On top of that, when there are increase of electrical discharges applied to the oil sample, it will allow free radical to cut the molecules in the oil, known as autocatalytic reaction. In addition, NE has superior water tolerance that can absorbs large amounts of water indicating a high saturation limit making precipitation of free water virtually impossible.

On the other hand, the water content of $\mathrm{NE}_{\mathrm{LV}}$ was not affected by the electrical discharges, where it shows value of water content in the range of between $141.56 \mathrm{ppm}$ and $147.54 \mathrm{ppm}$. The water content of $\mathrm{NE}_{\mathrm{LV}}$ is firstly decreased to $140.76 \mathrm{mg} / \mathrm{kg}$ at 200 electrical discharges, then increased slowly with increment of the remaining electrical discharges (200 to 1000 discharges). The reults is might be due to $\mathrm{NE}_{\mathrm{LV}}$ structure that consist of mainly saturated fatty acid hydrocarbon chain with hydrogen, where its not easily gave up it hydroxyl group to absorb water.

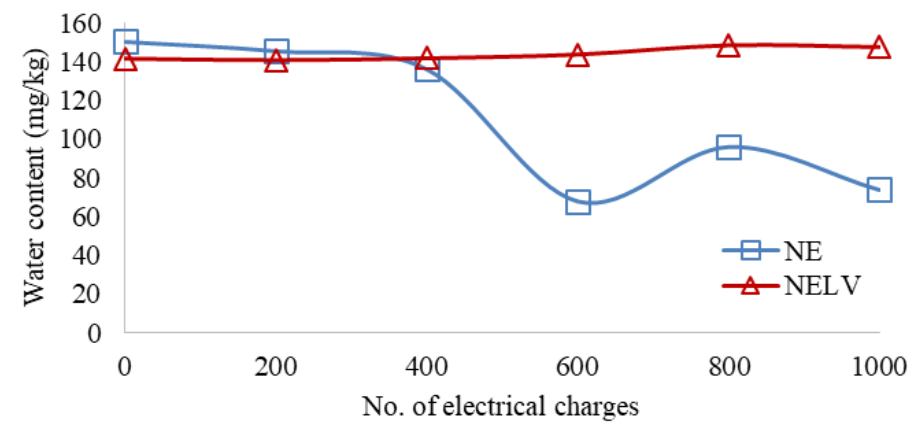

Figure 4. Effects of electrical discharges to water content of NE and NELV samples

\subsection{Acidity}

Figure 5 shows the changes in acidity of $\mathrm{NE}$ and $\mathrm{NE}_{\mathrm{LV}}$ after subjected to electrical discharges. The acidity of NE was gradually increase up to 400 discharges, but decreases afterwards with the number of discharges. In contrast, insignificant changes is detected for the acidity of $\mathrm{NE}_{\mathrm{LV}}$, indicating that $\mathrm{NE}_{\mathrm{LV}}$ is not much affected by electrical discharges. The different changes of acidity might be contributed to the stability of monoester $\left(\mathrm{NE}_{\mathrm{LV}}\right)$ compared to triglyceride (NE). Though the acidity of $\mathrm{NE}$ increased above $0.06 \mathrm{mg} \mathrm{KOH} / \mathrm{g}$ (i.e., the prescribed limit of "new natural ester fluids"), the level is $0.30 \mathrm{mg} \mathrm{KOH} / \mathrm{g}$ (i.e., within the stipulated limit for "continued use of in-service natural ester fluids"). In chemical point of view, the acidity (degradation by-products of natural ester) are mostly high molecular weight acid (HMA). HMA is not detrimental to cellulose material (e.g. paper and pressboard).

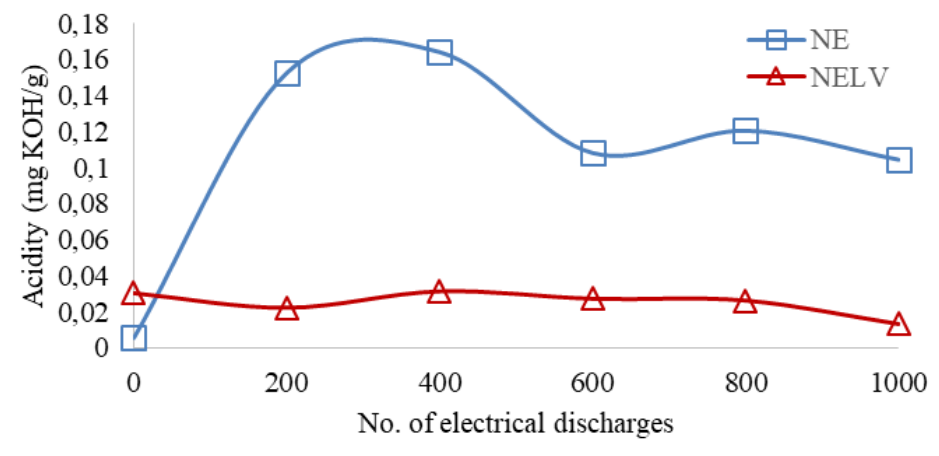

Figure 5. Effects of electrical discharges to acidity of HVNE and NELV samples 


\subsection{Breakdown voltage}

The dielectric breakdown voltage of an insulating liquid is vital as it represents the liquid's ability to withstand electric stress without failure. The dielectric breakdown voltage serves to indicate the presence of contaminating agents such as water, dirt, cellulosic fibers, or conducting particles in the liquid. Figure 6 show the breakdown voltage of $\mathrm{NE}$ and $\mathrm{NE}_{\mathrm{LV}}$. Generally, the breakdown voltage of NE is increase after electrical discharges were applied. The reason is because water content is also reduced at the sime time. The breakdown voltage of NE is initially decrease from $24.92 \mathrm{kV}$ to $16.77 \mathrm{kV}$, but then gradually increased to 46.87 after 1000 discharges. On the other hand, breakdown voltage of $\mathrm{NE}_{\mathrm{LV}}$ is firstly almost unchanged, up to 200 discharges. Then the breakdown voltage fluctuated (i.e., decrease from $25.47 \mathrm{kV}$ to $21.20 \mathrm{kV}$, but then gradually increased to 30.73 at 600 discharges and reduced again until $24.67 \mathrm{kV}$ after 1000 discharges. This might due to the presence of water in $\mathrm{NE}_{\mathrm{LV}}$, because water is one of the leading causes of electrical breakdown because it increases the ionic conductivity of the oil hence dropping the breakdown voltage. On top of that, electrical discharges could also change the molecules structures where number of electrons increased.

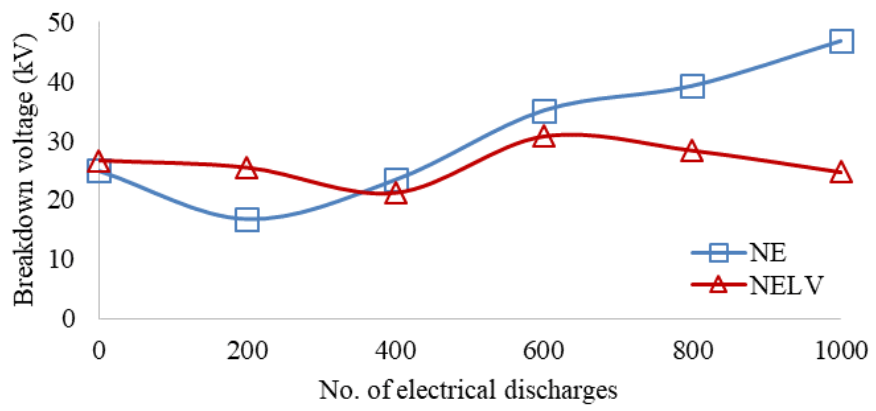

Figure 6. Effects of electrical discharges to breakdown voltage of NE and NELV samples

\section{CONCLUSION}

In this study, the effect of electrical discharges on two types of vegetable-based insulating oils; i) NE and ii) $\mathrm{NE}_{\mathrm{LV}}$ were investigated in terms of water content, acidity, and breakdown voltage. The applied electrical discharges were from 200 to 1000 discharges. It is found that NE (contain unsaturated fatty acid) can absorbs large amounts of water indicating a high saturation limit. Decrement of water content in NE resulting in increment of breakdown voltage of NE with the number of discharges. Other than that, the acidity of NE decreases with the number of discharges, which also indicating the changes on molecules structures of oil. In contrast, $\mathrm{NE}_{\mathrm{LV}}$ is found to be a stabil oil because its properties (water content, acidity and breakdown voltage) are not much affected by the electrical discharges. It is because $\mathrm{NE}_{\mathrm{LV}}$ is mostly contain saturated fatty chain thus not easily to form free radical from its molecules.

\section{ACKNOWLEDGEMENTS}

The authors acknowledge the support provided by the Universiti Teknikal Malaysia Melaka (UTeM) in funding the study. The authors also thank Mr. Mohd Wahyudi Md Hussain from Faculty of Electrical Engineering, UTeM for providing assistance on the preparation and measurements of the materials used in this study.

\section{REFERENCES}

[1] I. Fofana, "50 years in the development of insulating liquids," IEEE Electrical Insulation Magazine, vol. 29, no. 5, pp. 13-25, Sep. 2013, doi:10.1109/MEI.2013.6585853.

[2] I. Fernández, A. Ortiz, F. Delgado, C. Renedo, and S. Pérez, "Comparative evaluation of alternative fluids for power transformers,” Electr. Power Syst. Res., vol. 98, pp. 58-69, 2013, doi:10.1016/j.epsr.2013.01.007.

[3] M. Rycroft, "Vegetable oil as insulating fluid for transformers," Energize, vol. 4, pp. 37-40, 2014.

[4] J. Carcedo, I. Fernández, A. Ortiz, F. Delgado, C. J. Renedo, and C. Pesquera, "Aging assessment of dielectric vegetable oils," IEEE Electrical Insulation Magazine, vol. 31, no. 6, pp. 13-21, 2015, doi:10.1109/mei.2015.7303258.

[5] T. V. Oommen, "Vegetable oils for liquid-filled transformers," IEEE Electrical Insulation Magazine, vol. 18, no. 1, pp. 6-11, 2002, doi:10.1109/57.981322.

[6] CIGRE Working Group A2.35, "Experiences in service with new insulating liquids," Cigre. pp. 1-95, 2010.

[7] D. Bingenheimer, K. Rapp, F. Luiz, E. Del Fiacco, J. Mak, and V. Vasconcellos, "Sustainable Electrical Energy using Natural Ester Technology," in 21st International Conference on Electricity Distribution (CIRED), 2011, pp. 6-9. 
[8] K. Bandara, C. Ekanayake, and T. K. Saha, "Comparative study for understanding the behaviour of natural ester with mineral oil as a transformer insulating liquid," in 2014 IEEE Conference on Electrical Insulation and Dielectric Phenomena (CEIDP), 2014, pp. 792-795, doi: 10.1109/CEIDP.2014.6995828.

[9] B. S. H. M. S. Y. Matharage, M. A. R. M. Fernando, M. A. A. P. Bandara, G. A. Jayantha, and C. S. Kalpage, "Performance of coconut oil as an alternative transformer liquid insulation," IEEE Trans. Dielectr. Electr. Insul., vol. 20, no. 3, pp. 887-898, 2013, doi:10.1109/TDEI.2013.6518958.

[10] A. K. Das, D. C. Shill, and S. Chatterjee, "Potential of coconut oil as a dielectric liquid in distribution transformers," IEEE Electrical Insulation Magazine, vol. 36, no. 6, pp. 36-46, 2020, doi:10.1109/MEI.2020.9222633.

[11] BIOTEMP®, "BIOTEMP® dielectric insulating fluid," ABB. pp. 1-11, 2011.

[12] E. Coper, "FR3 fluid formulated for performance," Envirotemp, pp. 1-8, 2018.

[13] MIDEL ${ }^{\circledR} \mathrm{eN1204,} \mathrm{“MIDEL} \circledR$ eN 1204 natural ester transformer fluid (rapeseed),” M\&I Materials. pp. 1-4, 2017.

[14] Kiyoshi Wakimoto, "Features of eco-friendly transformers using palm fatty acid ester (PFAE), a new vegetable-based insulation oil," Meiden Review, vol. 163, pp. 39-45, 2015.

[15] J. Tokunaga, M. Nikaido, H. Koide, and T. Hikosaka, "Palm fatty acid ester as biodegradable dielectric fluid in transformers: A review," IEEE Electrical Insulation Magazine, vol. 35, no. 2, pp. 34-46, 2019, doi:10.1109/MEI.2019.8636104.

[16] T. Mariprasath and V. Kirubakaran, "A critical review on the characteristics of alternating liquid dielectrics and feasibility study on pongamia pinnata oil as liquid dielectrics," Renew. Sustain. Energy Rev., vol. 65, pp. 784-799, 2016, doi:10.1016/j.rser.2016.07.036.

[17] H. B. H. Sitorus, R. Setiabudy, S. Bismo, and A. Beroual, "Jatropha curcas methyl ester oil obtaining as vegetable insulating oil," IEEE Transactions on Dielectrics and Electrical Insulation, vol. 23, no. 4, pp. 2021-2028, 2016, doi:10.1109/TDEI.2016.7556474.

[18] N. Beltrán, E. Palacios, and G. Blass, "Potential of jatropha curcas oil as a dielectric fluid for power transformers," IEEE Electrical Insulation Magazine, vol. 33, pp. 8-15, Apr. 2017, doi:10.1109/MEI.2017.7866674.

[19] M. C. Menkiti, C. M. Agu, P. M. Ejikeme, and O. E. Onyelucheya, "Chemically improved Terminalia catappa L. oil: A possible renewable substitute for conventional mineral transformer oil," J. Environ. Chem. Eng., vol. 5, no. 1, pp. 1107-1118, 2017, doi:10.1016/j.jece.2017.01.037.

[20] M. Maharana, S. K. Nayak, and N. Sahoo, "Karanji oil as a potential dielectrics liquid for transformer," IEEE Trans. Dielectr. Electr. Insul., vol. 25, no. 5, pp. 1871-1879, 2018, doi:10.1109/TDEI.2018.007230.

[21] S. Ravulapalli, K. Ravindhranath, and M. Ramamoorty, "Preparation, characterization and feasibility analysis of methyl ester of Sesbania seeds oil (MESSO) as alternate liquid dielectrics in distribution transformers," RSC $A d v$., vol. 9, pp. 3311-3319, 2019, doi:10.1039/C8RA08378A.

[22] E. T. Nkouetcha, G. M. Mengounou, and A. M. Imano, "Elaboration and performance analysis of a bio-based insulating liquid from castor oil for power transformers," Open Access Libr. J., vol. 6, no. 5, pp. 1-16, 2019, doi:10.4236/oalib.1105404.

[23] BS EN 62770, "Fluids for electrotechnical applications - Unused natural esters for transformers and similar electrical equipment," BSI Standards. pp. 1-22, 2014.

[24] N. A. Muhamad, B. T. Phung, and T. R. Blackburn, "Dissolved gas analysis for common transformer faults in soy seed-based oil," IET Electr. Power Appl., vol. 5, no. 1, pp. 133-142, 2011, doi:10.1049/iet-epa.2010.0030.

[25] N. A. Muhamad, B. T. Phung, and T. R. Blackburn, "Application of common transformers faults diagnosis methods on biodegradable oil-filled transformers," Electr. Eng., vol. 94, pp. 207-216, 2012, doi:10.1007/s00202-012-0232-z.

[26] M. G. Niasar, N. Taylor, P. Janus, X. Wang, H. Edin, and R. C. Kiiza, "Partial discharges in a cavity embedded in oil-impregnated paper: Effect of electrical and thermal aging," IEEE Trans. Dielectr. Electr. Insul., vol. 22, no. 2, pp. 1071-1079, 2015, doi:10.1109/TDEI.2015.7076808.

[27] A. Reffas, et al., "Influence of thermal ageing and electrical discharges on uninhibited olive oil properties," IET Sci. Meas. Technol., vol. 10, no. 7, pp. 711-718, 2016, doi :10.1049/iet-smt.2016.0045.

[28] J. Wada, G. Ueta, S. Okabe, and T. Amimoto, "Techniques to inhibit transformer insulating oil degradationEffectiveness evaluation of the removal of degradation products using adsorbents," IEEE Trans. Dielectr. Electr. Insul., vol. 20, no. 6, pp. 2307-2316, 2013, doi:10.1109/TDEI.2013.6678884.

[29] T. F. Sipahutar, A. A. Kemma, N. Pattanadech, F. Pratomosiwi, Suwarno, and M. Muhr, "Effect of test method and needle plane configuration on partial discharge inception voltage measurement of mineral oil based on Weibull analysis," Procedia Technol., vol. 11, pp. 411-418, 2013, doi:10.1016/j.protcy.2013.12.210.

[30] ASTM D1533, "Standard test method for water in insulating liquids by coulometric Karl Fischer titration," ASTM International, pp. 1-5, 2012, doi:10.1520/d1533-20.

[31] ASTM D974, "Standard test method for acid and base number by color-indicator titration," ASTM International, pp. 1-7, 2014, doi:10.1520/d0974-21.

[32] ASTM D1816, "Standard test method for dielectric breakdown voltage of insulating liquids using VDE electrodes," ASTM International. pp. 1-5, 2012, doi:10.1520/d1816-12r19.

[33] ASTM D6871, "Standard specification for natural (vegetable oil) ester fluids used in electrical apparatus," ASTM International. pp. 1-4, 2008, doi:10.1520/d6871-17.

[34] ASTM D3487, "Standard specification for mineral insulating oil used in electrical apparatus," ASTM International. pp. 1-5, 2016, doi:10.1520/d3487-16e01. 


\section{BIOGRAPHIES OF AUTHORS}
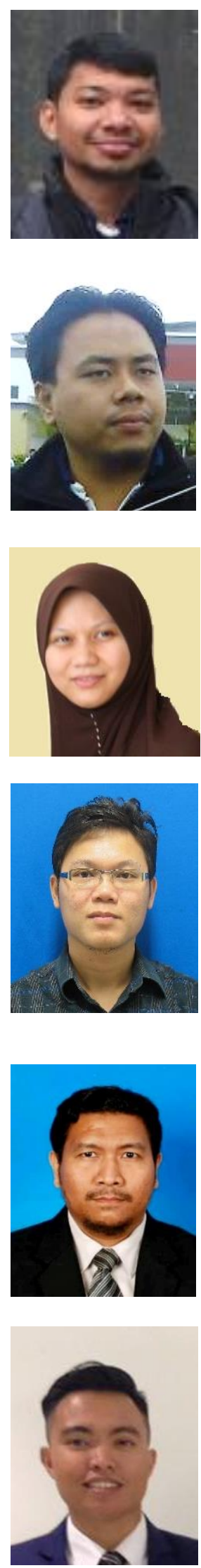

Imran Sutan Chairul was born in Kuala Lumpur, Malaysia, in 1984. He received his BEng. (Hons.) degree in Electrical Engineering from UTeM in 2008 and MEng. degree in Electrical Engineering from Universiti Tenaga Nasional in 2012. He is currently pursuing his $\mathrm{PhD}$ degree at UTeM, where his research is focused on vegetable-based transformer dielectric liquids.

Sharin Ab Ghani received his BEng. (Hons.) degree in Electrical Engineering from UTeM in 2008, MEng. Degree in Electrical Engineering from Universiti Tenaga Nasional in 2012, and PhD degree in Electrical Engineering from Universiti Teknologi Malaysia in 2019. Currently, he is serving as Senior Lecturer at Faculty of Electrical Engineering, Universiti Teknikal Malaysia Melaka. His research interests are centered on high voltage engineering, power equipment condition monitoring, green electrical insulation, design of experiments, and optimization. To date, his outstanding research works have been published in WoS-SCI (3) and Scopus (29) indexed journals. He also has experience in consultation work with industries related to electrical installation design, transformer condition assessment, and partial discharge analysis.

Nur Hakimah Ab Aziz received her BEng. (Hons.) degree in Electrical Engineering from Universiti Teknologi Malaysia, MEng. degree in Electrical Power Engineering from University of South Australia, Australia, and $\mathrm{PhD}$ degree in Electrical Engineering from University of Strathclyde Glasgow. She is currently serving as a senior lecturer at Universiti Teknikal Malaysia Melaka,, Malaysia. Her research interests include condition monitoring, diagnostics and prognostics, as well as ageing of dielectric insulations.

Mohd Shahril Ahmad Khiar was born in Selangor, Malaysia in 1984. He received his BSc. in Electrical \& Electronics Engineering from Korea University in 2008, Master's degree in Electrical Engineering from Universiti Tenaga Nasional in 2012, and PhD degree from University of Southampton, UK in 2019. He is currently serving as Senior Lecturer at Faculty of Electrical Engineering, UTeM and Head of High Voltage Engineering Research Laboratory in UTeM, where he is also the Deputy Head of Energy and Power Systems (EPS) Research Group. His research interests include high voltage engineering and insulation materials, sensors, condition monitoring for power equipment, and asset management. Since 2013, he has published over 20 refereed conference and journal papers associated with the transformer condition monitoring and asset management.

Muhammad Syahrani Johal was born in Malacca, Malaysia, in 1984. He received his BEng. (Hons.) degree in Electrical Engineering from UTeM in 2008. He is serving as Teaching Engineer at Faculty of Electrical and Electronic Engineering Technology, UTeM. $\mathrm{He}$ is currently pursuing his Master degree at UTeM, where his research is focused on vegetable-based transformer dielectric liquids. He also has experience in consultation work with industries related to electrical installation design.

Mohd Aizzat Azmi was born in Melaka, Malaysia in 1993. He received his BEng (Hons.) degree in Electrical Engineering from UTeM in 2018. Currently, he is serving as Facility Manager at EIC Advance Sdn Bhd, Putrajaya. 